\title{
Problematizing sovereignty in the Philippine Constitution-making of 1934-35
}

\author{
Problematizando a soberania na elaboração da \\ Constituição filipina de 1934-35
}

Maria Elena Pablo Rivera-Beckstrom ${ }^{1}$

\begin{abstract}
This paper discusses the competing claims by Filipino constitution-makers in 1934-35 about the scope of the constitution being drafted under American sovereignty. I argue that the democratic process by which Filipinos chose their delegates to the constitutional convention and the ratification of the constitution through a plebiscite, and the facticity of being colonial subjects drafting a constitution gave way to two perspectives on sovereignty. The first perspective follows the doctrine of popular sovereignty while the second follows the notion of state sovereignty. These two perspectives competed, but were also conflated by, the constitutional convention delegates' nationalist interpretation of constitution-making.
\end{abstract}

\section{KEYWORDS}

Filipino constitutional lawmaking; democracy, doctrine of popular sovereignty; doctrine of state sovereignty.

\section{RESUMO}

Este texto discute as vertentes dos constituintes filipinos da Carta de 1934-1935 sobre o escopo da constituição que se elaborava baixo a soberania americana. Eu discuto que o processo democrático que levou a escolha dos constituintes pelos filipinos de seus representantes da assembleia constituinte e ratificação da Constituição via plesbicito, e o fato de termos súditos coloniais elaborando sua própria constituição deu origem a duas perspectivas referentes a soberania. A primeira segue a doutrina da soberania popular enquanto a segunda segue a noção de soberania do estado. Estas duas perspectivas competiam entre si, embora ambas sido combinadas pela interpretação nacionalista sobre a elaboração da constituição pelos constituintes.

\footnotetext{
1 Ph.D. in Sociology from the New School for Social Research. Former Visiting Assistant Professor with the Legal Studies Department of the University of Illinois at Springfield and at Bowdoin College. Researcher LSA/CRN 1 "Comparative Constitutional Law and Legal Culture: Asia and the Americas".
} 


\section{PALAVRAS-CHAVE} estatal.

Processo de elaboração da constituição filipina; democracia; soberania popular; soberania

\section{INTRODUCTION}

There was bewilderment, even implicit mockery, in the note given to U.S. High Commissioner Frank Murphy by one of his aides regarding the quoted statement by Justice Recto, the chair of the Philippine Constitutional Convention which framed the 1935 Philippine Constitution. By underscoring the words 'act of sovereignty' and 'free', Kemp was emphasizing that Justice Recto had forgotten that unlike most cases of constitution-making where there is an assumption of state sovereignty, such was not the case in the 1934-35 Philippine constitution-making episode.

The Philippines was under the sovereignty of the United States when Filipinos drafted their constitution for their commonwealth government as well as for the soon-tobe independent nation. Independence would come after ten years of commonwealth status as guaranteed by Section 10 of the Philippine Independence Act of 1934 (PIA) passed by the U.S. Congress. The law authorized the Philippine Legislature to provide for the election of delegates that would draft the constitution for the Philippine Commonwealth. It also stipulated mandatory provisions that the constitution should be republican and contain a bill of rights, as well as provisions governing the commonwealth's political, legal and economic relations with the United States prior to independence. The law stipulated that the latter provisions could be part of the constitution or as an appended ordinance to the constitution. The constitution had to be approved by the U.S. President to make sure that it is in accordance with the mandatory provisions of the PIA before it could be subjected to ratification by Filipinos through a plebiscite.

There are two aspects of the Filipino constitution-making under colonial status which led to the competing claims on what should be the scope of the constitution during the constitutional convention's deliberations. One was the democratic process by which Filipinos chose their delegates to the constitutional convention and the ratification of the constitution through a plebiscite, and the second, the facticity of being colonial subjects drafting a constitution. I argue that these two aspects relate to the question of sovereignty which were at play during the deliberations of the constitution - popular sovereignty and state sovereignty. These two perspectives competed, but were also conflated by, the constitutional convention delegates' interpretation of Philippine constitution-making under the conditions of colonialism. While these two conceptions do not necessarily clash, it is necessary to differentiate the two to explain the Philippines' political status as a colony during the 1934-35 that led to the constitutional convention delegates' competing conception of sovereignty with its consequent political dynamics among them.

This paper is mainly an analysis of the competing claims on the concept of sovereignty based on the proceedings of the making of the Philippine 1935 Constitution and other primary documents. Although there was a larger historical milieu that was playing out with regards to the debate on the Philippine independence from the United States, That larger context have been tackled by many historians and scholars of the American colonial period in the Philippines while the making of the 1935 Philippine Constitution itself has not been subjected to any closer study. 
I first discuss the conceptual underpinnings of the two notions of sovereignty which surfaced during the deliberations on the scope of the constitution. I then present the Cuban constitution-making episode of 1901 as a precursor and a lesson learned for the United State in handling its impositions on its colony's constitution-making. I then proceed to analyze the deliberation and decision on the scope of the constitution that shows two opposing sides, both of which interpreted the law passed by the U.S. Congress, which gave way to the drafting the constitution, through the lenses of their nationalist sentiments. One side saw the constitution-making episode as an act of sovereignty despite the colonial condition by boldly interpreting the PIA, while the other was more reserved in its interpretation of the act. This decision to adopt a constitution for both the Philippine commonwealth and republic shows that one version of nationalism won, one that was more assertive and saw the American's 'We the People' as their example.

\section{SOVEREIGNTY AND THE PHILIPPINE INDEPENDENCE ACT}

Central to the deliberation on the scope of the Philippine constitution was the notion of sovereignty. Two perspectives on sovereignty were at play during this deliberation: normative and sociological-legal. These two perspectives competed, but were also conflated, by the constitutional convention delegates' interpretation of the Philippine constitution-making under colonial condition. The first perspective follows the doctrine of popular sovereignty which, although historically associated with the French Revolution and the American constitution-making of 1787-89, is nevertheless considered normative, and legally indefinable (Kis 2003). The other perspective of sovereignty i.e., state sovereignty, is more sociological and has juridical/legal bases. While these two perspectives do not necessarily clash, and are conceptually interdependent (See Benhabib 2009), differentiation of the two perspectives is necessary in explaining the Philippines' political status as a colony during the 1934-35 constitution-making which led to the ambiguous conception of sovereignty by the delegates.

As previously mentioned, the United States Congress passed a law for its colony, the Philippines. By virtue of Section 10 of the Philippine Independence Act of 1934 (PIA) Philippine independence was set and the existing Philippine Legislature was authorized by the PIA to provide for the election of the delegates for the constitutional convention which would draft the constitution of the Philippine Commonwealth. In the same law, the U.S. Congress mandated that the constitution should be republican and should contain a bill of rights. It also stipulated mandatory provisions that would govern the political and economic relations between the Philippines and the United States. Despite being a colony, as the PIA authorized, Filipinos selected their own representatives for the constitutional convention through a democratic election based on the Convention Bill (No.4125) passed by the Philippine Legislature on May 5, 1934 and signed into law by the Governor General, Frank Murphy. In the convention bill, each elective representative district were allotted two elected delegates; the provinces of Mindanao and Sulu and each subprovince of the Mountain Province also had two delegates each and another two delegates for Baguio City. All in all, two hundred delegates constituted the constitutional convention. Qualified voters, male and twenty-one years of age ${ }^{2}$, were able to participate in the

2 The qualifications of the voter were based on a 1916 law which was amended in 1924 to allow those who cannot read and write to vote in the "presence of someone whom they trusted" (Nohlen, et al.2001: 188). Based on a law passed by the Philippine Legislature prior to the 1934-35 constitution-making, women suffrage was to take effect by January 
democratic elections process, including that of ratifying the constitution in a plebiscite after it had been approved by the U.S. President. This democratic political process while being a colony gave way to the two perspectives of sovereignty as interpreted by the Filipino delegates to the convention.

Defining sovereignty is problematic in itself due to the long tradition of the discourse. But what most definitions, or attempts at such, always go back to was Bodin's (1992) definition as the absolute and perpetual power of a commonwealth (1), and Austin's (1995) notion of sovereignty as supreme command. Both definitions point to the highest authority subject to no one, although Bodin makes an exception for divine or natural laws that the sovereign is subject to. Austin's sovereign, whose commands are laws backed by sanction, is in the habit of being obeyed but does not obey anybody. These conceptions were based on the particular context when royalties ruled and the king was the sovereign. However, the meaning of sovereignty shifted as history took its course. The sovereign (supposedly) became the people and sovereignty of the state played an important role in international relations.

The normative perspective of sovereignty is equated with the doctrine of popular sovereignty. According to this doctrine, the ultimate source of legitimacy, the sovereign, is the people. Abbe Sieyes (1964), in the context of the French Revolution of 1789, conceived of popular sovereignty as the general will of the people, or the nation. For him, the nation only needs its own existence to be legal and legitimate. "The manner in which a nation exercises its will does not matter; the point is that it does exercise it; any procedure is adequate, and its will is always the supreme law" (Ibid 128). It is in this context where Sieyes distinguished between the constituent/constituting power (pouvoir constituant) and constituted power (pouvoir constitué) that was to influence constitutional theory in relation to the founding act of the constitution and of the state. He locates the constituent power on popular sovereignty or the nation in the state of nature and is therefore pre-legal, not bound by any legal procedures or legality. The constituted power, on the other hand, is whatever powers the constitution delegate.

Unlike Sieyes, Arendt (1965) believes that the constituent power does not lie on the general will (in the state of nature) because "the so-called will of a multitude (if this is to be more than a legal fiction) is ever-changing by definition, and that a structure built on it as its foundation is built on quicksand" (163) as exemplified in France's constitutional experience. Sieyes's conception, according to her, could not ultimately establish a republic founded on laws because it only replaces the "monarchy or one-man rule with democracy or rule by the majority'. A republican constitution must be established through a general political participation, but for her it is in the United States' example of organized political bodies representing the people which allowed for greater participation, than in Sieyes' will of the people in 'state of nature,' which offers stability. The stability of the former stems from the rule of law afforded by the creation of a constitution by authorized bodies that were themselves limited by established laws, and brought the drafted constitution for deliberation and ratification by the people. The

1,1935 . As a result of the deliberation in the constitutional convention, a compromise to women suffrage was included in the 1935 Philippine Constitution which states that "The National Assembly shall extend the right of suffrage to women, if in a plebiscite which shall be held for that purpose within two years after the adoption of the Constitution, not less than three hundred thousand women possessing the necessary qualifications shall vote affirmatively on the question." On April 30, 1937, a plebiscite on women suffrage was held. Out of the 588,052 qualified women registrants, 492,032 votes were cast, with 447,725 affirmative votes for women suffrage and 44,307 negative votes (See Hayden 1942). 
American constitution then is an act of the people. This, for Arendt, however, does not translate to popular sovereignty as the constituent power like in Sieyes.

Arendt views sovereignty, popular or otherwise, negatively. She conceives of it as control, domination (assertion of will) and tyranny regardless whether the sovereign is a monarch or 'the people' (See Arato and Cohen 2009; Kalyvas Ibid) and did away with the concept of sovereignty altogether because it was contrary to her conception of politics as deliberative, equal and plural (Arato and Cohen Ibid). But as Arato and Cohen (Ibid) point out, Arendt's conception of sovereignty lacks a more nuanced conception of sovereignty. Following Carré de Malberg, the authors distinguish between organ sovereignty and state sovereignty. According to them, it was mainly organ sovereignty that the Americans banished in Arendt's construction (i.e. one branch usurping plenitude of powers), but not state sovereignty (Ibid). The Americans banished organ sovereignty through federalism and separation of powers where no one organ can fully claim popular sovereignty and also popular sovereignty as the constituent power as defined by Sieyes and as pointed out by Arendt. The latter, as already mentioned, was banished by placing the constituent power on organized bodies instead of in 'state of nature'. However, while organ sovereignty was banished in the American experience, Arato and Cohen argue, popular sovereignty was not necessarily banished. Its role, according to them, was "to point to the impossibility and illegitimacy of any single democratic organ to speak for the People as a totality" (312). With this argument, the popular sovereign stands outside the constitution and the body politic as 'an ultimate limiting concept' (Ibid).

Popular sovereignty, as a normative concept, came to be understood as empirically embodied in democratic procedures and representative institutions where the people express its will. It became, to borrow Habermas' (1996) term, 'proceduralized popular sovereignty' (298) and institutionalized popular sovereignty. These institutions and procedures include elections, assemblies and periodically, plebiscitary leaders (especially through the president (Arato and Cohen op. cit.) ${ }^{3}$. Regardless of the problems of exclusion and real representation in these institutions, it has been accepted that the people as the sovereign are approximately represented through these democratic procedures and institutions of representations.

With regards to the more sociological and juridical perspective of sovereignty, in international law and relations, sovereignty commonly refers to state sovereignty, which combines two dimensions of sovereignty namely internal and external. These dimensions are interdependent and complementary (Arato and Cohen op.cit..; Benhabib op.cit.; Philpott 1997). There can be no external sovereignty without an internal sovereign or a supreme authority within a territory. A sovereign state, therefore, presupposes a territory that is politically and legally independent and geographically separate (Jackson 2007) or what James (2000) calls jurisdictional independence. The sovereign state has the supreme authority within its territorial jurisdiction despite the fact that it might be subject to international law that limits this jurisdiction such in the case of foreign diplomats and other 'accepted international legal obligations' (Ibid). It also follows that the sovereign state has political independence: "it can successfully look after itself, can chart and follow its own independent course" (Ibid 7-8) and can assert this internally and externally. This political independence, however, can vary in international relations, depending on how powerful a sovereign state is, relative to other sovereign states (Ibid). This means that the

\footnotetext{
${ }^{3}$ Arato and Cohen also point out and show, however, that historically, the American's plebiscitary presidency and the executive's 'inherent and unenumerated powers' in foreign affairs, along with the president's emergency powers, gave rise to sovereignty that Arendt tried to banish.
} 
more powerful states could better achieve its international goals compared with the other sovereign states, depending on the issue and the context (Ibid). Generally speaking, a sovereign state is recognized as sovereign beyond its territorial boundaries and prevents interference from outside or by other foreign states (Philpott Ibid). Further, such "political and legal insulation from foreign governments [is] acknowledged by international law" (Jackson op.cit.: 6).

Although jurisdictional and political independence qualities of state sovereignty may not be absolute (as there can be some limitations to them as demonstrated in the case of sovereign states constituting the European Union), James (op.cit.) asserts that a sovereign state may not be constitutionally linked to another sovereign state's constitution or any wider constitutional scheme, no matter how loosely. If such constitutional independence does not exist, the territorial entity is not sovereign. As he further asserts, sovereignty, in the sense of constitutional independence cannot exist in gradation. It is not a case of 'more or less' - "The relevant entity is sovereign (and therefore 100 per cent sovereign) or lacks sovereignty - lacks it totally" (14).

Based on the qualities or various senses that state sovereignty is used (i.e. jurisdictional, political and constitutional independence), James (Ibid) provides the three key features of sovereignty: legal, absolute and unitary. Being legal means that the sovereign state is founded on law, based on the state's own constitutional law. That it is legal "indicates the possession by the state of a set of legal arrangements of a certain kind - those which equip it with an independent constitution" (13). James equates sovereignty's absolute condition to constitutional independence - the quality of being sovereign is absolute, it is either present or not at all. A sovereign state may be politically weak but this weakness does not detract from its sovereignty or from its constitutional independence. As James adds, "Whether or not a governed territorial entity is constitutionally independent is a matter of fact which in principle can only be answered negatively or positively" (14). Lastly, a sovereign state is unitary. Despite the internal and external dimensions or aspects of sovereignty, it remains to be a singular, unitary whole. As explained above, a state may not be externally sovereign if it does not have sovereignty within its jurisdiction. Unitary means that for both of its internal and external affairs, the state is sovereign. This is also to say that even if the sovereign state passes over its decisions on internal or external matters to an international body or another state, ultimately, it is still the sovereign state's decision to grant such rights to another.

James' analysis of sovereignty is conceptually neat and empirically verifiable, more or less. He explains that once a state becomes constitutionally independent and thus, sovereign, this does not automatically mean that it can make agreements or engage in diplomatic relations with other sovereign states. Constitutional independence is just a step towards this purpose. A more crucial step is recognition (prior to establishing diplomatic relations and diplomatic missions). A new sovereign state must be recognized and be deemed as having met the requirements of sovereign statehood. Constitutional independence does not guarantee recognition by foreign sovereign states and inclusion to the international community of sovereign states. The Philippine revolutionary government's declaration of independence from Spain in 1898 and ratification of the Philippine Constitution (aka Malolos Constitution) demonstrate the significance of recognition by other sovereign states. Despite its constitutional independence, it was not recognized as sovereign by other sovereign states. Its emissary to the peace negotiations between the United States and Spain on December 1898 in Paris (Treaty of Paris 1898) after the Spanish- American War, Felipe Agoncillo, was excluded and ignored; he was 
not even permitted to attend the conference (Zaide 1999). Although it may be argued that the lack of recognition was based on the fact that the Philippine Republic has not been properly established yet at the time of the conference, this case still demonstrates the importance of recognition by other states and that constitutional independence does not guarantee such recognition. This case can also be explained by Malanczuk and Akehurst's (1997) assertion that

peoples under colonial rule are not usually regarded as forming a new state until their struggle for independence has been successfully completed. The view that the colonial power no longer has sovereignty over its colony would mean that no state would have sovereignty over the territory in question while the inhabitants were still struggling for independence - a conclusion which would raise all kinds of practical and theoretical difficulties. These difficulties can be avoided if we accept that the colonial power retains sovereignty until the people have been allowed to exercise their right of self-determination (334-35).

Canada, on the other hand, demonstrates a case where lack of constitutional independence is not considered a hindrance to be recognized and treated as sovereign by the international community. As early as 1919, it was already recognized as a sovereign state even though it was only constitutionally repatriated in 1982; prior to this, the ultimate constitutional authority in Canada was the Judicial Committee of the British Privy Council (Holsti 2004). Even without sovereignty, it was a founding member of the League of Nations (Ibid). This case demonstrates that as Holsti (Ibid) states, "As long as the international community confers sovereign status on a state, it is sovereign, and it enjoys all the rights and must meet all the obligations of sovereignty" (138).

These two examples, Philippines and Canada, show the importance of recognition of sovereignty by other sovereign states. What makes the determination of a sovereign status is not a black-and-white matter, with only legal requirements for its achievement. Recognition, as Malanczuk and Akehurst's (op.cit.) claim, is political, as well as based on factual situations. Because of the many nuances of sovereignty in their empirical manifestations, that is, how and why one state may be recognized as sovereign or not, Cooley and Spruyt (2009) argue that "sovereignty is rarely absolute" (4). Instead, he argues that "sovereignty consists of a bundle of rights and obligations that are dynamically exchanged and transferred between states" (ibid) like the cases of the member states of the European Union, Iraq (with the lingering presence of American troops under its own command and control) or when some decolonized or newly independent states are either granted 'partial sovereignty'. These cases, however, only point to partial sovereignty in internal affairs (internal sovereignty). When it comes to external sovereignty, the absoluteness of who is sovereign gets clearer. Despite the muddled internal sovereignty of the cases mentioned, including Canada, if a state has external sovereignty, it is considered sovereign. This means that as long as the international community recognizes a state as sovereign, then, it is sovereign.

External sovereignty is also crucial in the determination of sovereignty status of colonial governments who might seem to possess internal sovereignty but not external sovereignty. Jackson (op.cit.) explains that although a colonial government might have autonomy, it is still not sovereign and only has the delegated authority by an imperial state that has the final authority over the colony. Thus, the latter has sovereignty over it. Even if the colonial government has autonomy in its internal affairs, it cannot be said to 
have internal sovereignty because the metropolitan state could still intervene in its internal affairs.

Also, the laws of the colony are usually subordinate to those of the imperial or metropolitan state. Even when there is a local law-making body, it is still commonly subject to the laws of the metropolitan state. As Jackson (Ibid) states, "If a state's government were in a position of legal subordination to a foreign government, that authority would be the sovereign, and the state would be an American-style 'state', a colony or some other kind of integral unit or dependency of a larger sovereign state" (10). Being legally subordinate also means that a colony does not have legal sovereignty (similar to James' constitutional independence). This is demonstrated, for example, in the cases of the British colonies where judicial review was an imperial means of control of its colonies represented by the British Judicial Committee of the Privy Council in London (McWhinney 1981). The council, as a British authority, had the ultimate decision on laws and cases pertaining to the colonies and whatever laws and decisions the colonies pass may be scrutinized and revoked by the council (Ibid). Even after some colonies have been granted 'Dominion' or 'Commonwealth' status, Britain retained its legal sovereignty over them. Canada's achievement of legal sovereignty, for example, was a protracted process. Despite Britain's passing of the Statute of Westminster in 1931 which officially gave legislative equality to the British Dominions, including Canada, the British Parliament still had residual powers over the dominions. Even if the British Parliament could no longer effectively legislate for the dominions, it could still do so if requested and consented by the parliament of the dominion.

However, the British Parliament could still legislate for the Canadian provinces and any changes on Canada's constitution could only be made by the British Parliament. With the British North America Act of 1949, Canada was given limited powers to change its constitution without the British Parliament's consent. Canada officially became legally sovereign only after its constitution was repatriated in $1982^{4}$.

In other literature, legal sovereignty is defined in terms of the supreme giver of law within a state and is usually associated with parliamentary sovereignty (Dicey1885; Barnett op.cit.). However, it is useful as an analytical category for determining the legal sovereign in a colony and the sovereignty of a decolonized country. This, however, also gets obscured because as the Canadian case exemplifies, as mentioned above, the latter's lack of legal sovereignty was not an obstacle to its recognition as a sovereign state. As an empirical indicator of sovereignty, the question of legal sovereignty is useful for the discussion of colonial governments, yet it detracts from the determination of whether or not a decolonized country is considered a sovereign state. As an indicator of state sovereignty, external sovereignty is stronger than legal sovereignty. The latter, however, is still useful in cases where external sovereignty is already non-existent to further prove a non-sovereign status.

Overall, the normative and sociological and juridical perspectives on sovereignty provide a starting point for raising the issues that surfaced during the deliberation on the scope of the constitution to be drafted by the Philippine constitutional convention.

\footnotetext{
4 For discussions on Canada's legal history and applicable laws see Russell 2004 and Barnett 2004:63-66.
} 


\section{PRECURSOR TO THE U.S.'S DEMOCRATIC REPRESENTATION IN COLONIES' AND PROTECTORATES' DECOLONIZATION CONSTITUTION-MAKING}

It is interesting to note that of the few cases of constitution-making under American sovereignty, the status of independence with external sovereignty was either not granted or at least obscured, but the constitution-making went through a democratic process of representation. The Philippines had its constitution-making prior to Puerto Rico but both retained its colonial status after constitution-making. A bit further back in history reveals that another constitution-making under the auspices of the United States took place, with similar ambiguity of full sovereignty: Cuba of 1901.

It might be remembered that because of Article IV or the Teller Amendment in the Joint Resolution of the U.S. Congress in April 20, 1898 that attempted to recognize Cuban independence, the United States could not legally and categorically colonize or annex Cuba. The Teller Amendment, however, did not restrain the U.S. from having sovereignty over the island. Since the American officials thought that the Cubans could not be "entrusted with their own government (Report of the Military Governor of Cuba 1901: 180), the U.S. remained in Cuba after the Spanish-American War until they deemed it was time for the Cubans to adopt their own constitution. A series of orders baffled the Cubans as to what must be ultimately done regarding what the U.S. demanded on the orders that were passed. Orders 301 and 316 by the American military governor served as the legal bases for the election of delegates and adoption of a constitution, similar to the U.S. Congress' Philippines Independence Act of 1934. Order 301 established the election of delegates while Order 316 established the election regulations. But there was also the Civil Order 455, where General Leonard Wood told the Cuban Constitutional Convention, "It will be your duty, first, to frame and adopt a Constitution for Cuba, and, when that has been done, to formulate what, in your opinion, ought to be the relations between Cuba and the United States" (Robinson 1901b. Emphases added); this was a clarification of a supposed misunderstanding which resulted to the Cuban protest against including the U.S.-Cuba relations in the Cuban Constitution. The Cubans understood that the order implied that 'the constitution and the matter of relations [with the U.S.] were wholly separate and distinct from each other' (Robinson Ibid:673) and the American officials in Cuba understood similarly. But Washington officials meant differently which was why the Platt Amendment was passed.

The Platt Amendment was an amendment to the Army Appropriations bill. It provided for the following: restrictions on Cuba's conduct of foreign relations with regards to contracting treaties with foreign powers, restriction on their power to incur debt, U.S.'s right to intervene to preserve Cuban independence, ratification of all U.S. Acts in Cuba during its military occupation, execution and extension of sanitation plans, omission of the Isles of Pines from the proposed constitutional boundaries of Cuba, retention of naval stations, and lastly, the said provisions must be embodied in a permanent treaty with the United States. Initially, the Cuban convention rejected the Platt Amendment thinking that it did not have the force of law as a statute of the United States given how it evolved and was relayed to the Cuban convention. After much protest, argument and haggling with the administration in Washington, the Cubans realized that it only had two choices: accept the Platt Amendment thereby limiting their sovereignty, or have no sovereignty at all (Pérez 1986:52-55). The Platt Amendment was accepted by the convention on June 12 with a vote of 16 to 11 (with four members absent), and the 
law was appended to the Cuban constitution. Thus, through the Platt Amendment Cuba became, in international law, a U.S. protectorate. They had a democratic election of their delegates to the constitutional convention, but the convention also had to swallow the bitter pill of promulgating a constitution under U.S. sovereignty. They could self-govern but under the Platt Amendment, the U.S. could (and did) intervene, even in their domestic affairs.

Cuba was a lesson learned for the U.S. in terms of imposing its demands over a colony and using the law for granting 'independence' and setting the making of the constitution as a tool for maintaining its sovereignty over a territory. Because of the ambiguities experienced by the Cubans in the U.S.'s ever evolving instructions to the Cuban constitutional convention and the Cuban stance against the U.S. demands, the U.S. became more explicit in imposing its terms prior to the beginning of a constitutionmaking in a colony or occupied territory. Its succeeding decolonization laws for the Philippines, Puerto Rico (U.S. Congress' Public Law 600 for the 1950 constitutionmaking) and later for Iraq were less ambiguous than what happened in Cuba. The Philippine Independence Act of 1934 (PIA) made explicit the terms of the relations between the U.S. and the Philippines, which the delayed Platt Amendment tried to achieve in Cuba, and handed it to the Philippines to accept. Without this acceptance, there could have been neither constitution-making nor foreseeable independence. The U.S. managed to get what it wanted in its relations with the Philippines through the PIA. As with the Platt Amendment, it managed to retain ultimate sovereignty over the Philippines masking somewhat the self-interested motivations. It appeared to be benevolent because it was finally granting the Filipinos their long-awaited independence, despite the self-interested motivations behind the act ${ }^{5}$.

\section{DECISION ON DRAFTING A CONSTITUTION FOR THE COMMONWEALTH AND REPUBLIC}

Just like Cuba (1901) and Puerto Rico (1950), the Philippine 1934-35 constitutional convention did not have a 'plenitude of power' (Arato 2009:1) because of the colonial condition and the limitations imposed by the United States. The United States retained its sovereignty over the colonies after a constitution was drafted, although a democratic process of electing their delegates to the constitutional convention took place. But the Philippine case also differed -it was promised independence after the commonwealth period of ten years while Cuba and Puerto Rico's legal statuses had the quality of being indefinite although Cuba's Platt Amendment was later repealed in 1934 through the Treaty of Relations between the United States and Cuba. The U.S., however, retained sovereignty over Cuba's Guantanamo Bay. The Philippine case was also similar to Puerto Rico and Cuba with regards to the laws that made the constitution-making possible. The corresponding laws for the Philippines and Puerto Rico, PIA and Public Law 81-600 respectively, dictated that the constitution should provide for a republican form of government and should have a bill of rights. There was no such imposition in the orders for Cuba. But Cuba and the Philippines' laws were also similar because it both

\footnotetext{
5 For a detailed study on the U.S. motivations and politics behind the Philippine Independence Act of 1934, see Philippine Research Bureau 1935, Grunder and Livezey 1951, Jenkins 1954, Friend 1965, Kirk 1974, Brands 1992, Pomeroy 1994, Golay 1997.
} 
covered the relationship between the colony and the metropolitan state. For the Philippines, specifically, the PIA also dictated some parameters for the political and economic relationship during the ten-year commonwealth status, quite similar to the Platt Amendment but more elaborate. To name a few, the PIA mandated that the citizens of the Philippines owe allegiance to the U.S.; government officials recognize and accept the supreme authority of the U.S.; the U.S. maintained the right to appropriate property, maintain military reservations and call Philippine military into service; Commonwealth court decisions were subject to review by the U.S. Supreme Court; trade relations specified limitations on export of Philippine products to the U.S.; and limited Filipino migration to the U.S. Also, during the commonwealth period, the American Governor General would be replaced by the U.S. High Commissioner as the representative of the U.S. President in the Philippines and must be recognized as such by both the Philippine Commonwealth Government and American military and civilian personnel, with access to all government records and information. The Philippines was also not allowed to contract debt from foreign countries without the U.S. President's approval. The acts of the Philippine Legislature had to be either reported to the U.S. Congress or approved by U.S. President, especially those that pertained to currency, coinage, imports, exports and immigration. More importantly, foreign affairs were to be 'under the direct supervision and control of the United States' (PIA, Sec.2 (10). These provisions, even if not all of the PIA, already explicitly indicate that the commonwealth, unlike the British Commonwealth, had neither external sovereignty nor full internal sovereignty. Clearly, the United States retained its sovereignty in the Philippines and granting of independence after the ten-year commonwealth period was not even a certainty due to the provision in the PIA that tied the ratification of the constitution to independence (i.e. the vote for the constitution was also a vote for Philippine independence), as will be discussed later. How, then, could have the Filipino delegates to the constitutional convention perceived it otherwise?

Filipinos had a chance to draft a constitution with full sovereignty after independence, and could have opted to draft an interim constitution for the ten-year period; but not all of the Filipino leaders and members of the constitutional convention had the clarity regarding their lack of state sovereignty. The formulation of some provisions of the PIA and the long years of struggle and anticipation for independence, all together, marked the constitution-making episode as a historic moment. As such, many leaders and constitutional delegates saw the significance of their roles as framers of the constitution. Even prior to the opening of the convention, the Philippine Senate President and leader of the majority Antis ${ }^{6}$ party, Manuel L. Quezon, organized a caucus where he "laid special emphasis upon the fact that as the Constitution to be drafted was not only for the Commonwealth but also for the Republic, it would mean greater glory for the 'Antis' if, dominating the Convention as they did, nevertheless they should work harmoniously with the minority in drafting the Constitution" (Aruego 1949:8 Emphasis added). The leader and delegates knew that it was a momentous period for the country; but the Philippines was not sovereign yet, and some delegates were more aware of this. Thus, they did not have the same position regarding the scope of the constitution. Whether

6 The Antis is the Philippine majority political party. This name was derived from the party's opposition to the initial Philippine Independence Act that was initially approved by the US Congress, vetoed by the President Hoover, overturned by the US Congress, but was finally rejected by the Philippine Legislature. During the campaign for whether to accept or reject the bill, the Philippine political spectrum and opinion was divided between those who were for the independence act also known as the Pros and those who were opposed known as the Antis. 
or not to frame a constitution for both the republic and the commonwealth became a contentious point in the convention which caused a deadlock and a prolonged deliberation of almost four weeks.

\section{THE OSIAS RESOLUTION}

The discussion on the matter of the scope of the constitution was brought to the floor of the constitutional convention on August 28, 1934 through a resolution sponsored by Delegate Camilo Osias. The resolution put forth the necessity of defining the scope of the constitution to be drafted so as to guide the work of the convention. According to Osias, the scope of the constitution to be drafted should be both for the republic and the commonwealth government as authorized by the PIA when it 1) stated that the mandatory provisions could be placed in an ordinance appended to the Constitution, 2) provided that "the independent government shall be proclaimed under the Constitution in force at the time of the advent of independence," 3) provided in Section 2(b) that the "officials elected and serving under the constitution adopted pursuant to the provisions of this Act shall be constitutional officers of the free and independent government of the Philippine Islands and qualified to function in all respects as if elected under such government, and shall serve their full terms of office as prescribed in the constitution," and, 4) stated in Section 10 of the Act dealing with the withdrawal of American sovereignty provided that upon the withdrawal of the U.S. on the 4th of July immediately following the expiration of the ten-year period, the U.S. "shall recognize the independence of the Philippine Islands as a separate and self-governing nation and acknowledge the authority and control over the same of the government instituted by the people thereof, under the constitution then in force" (PCC Vol.I 1969: 516-17). These citations of the provisions of the PIA, which emphasized continuity of government, constituted the legal bases for Delegate Osias' resolution.

Osias' interpretation of the PIA, and those who agreed with him, was bold, motivated by their anticipation for the Philippine Republic. For so many years, Filipinos had wanted independence and the passing of the PIA finally gave them the opportunity to seize the moment and establish the republic, if only its constitution. Driven by the nationalist fervor of the time, they did not see their colonial condition as a limiting factor for drafting a constitution also for the republic. What was more important for them was that they were drafting a constitution, and as the other models of constitution-making available at the time taught them, a people who had drafted a constitution drafted it for their republics. Given the democratic process of their election as delegates to the constitutional convention, they saw themselves as the rightful representatives of the Filipino people. As such, the process of their election captured popular sovereignty. But it was popular sovereignty without state sovereignty.

Not all delegates agreed with the Osias Resolution and questioned the legal bases for adopting a constitution for the republic. The opponents argued that the PIA did not authorize the convention to frame a constitution also for the republic because 1) the U.S. Congress could have specifically stated that it shall be a constitution for the commonwealth and for the republic if that was their intention, 2) there was no certainty that the Filipino people would desire independence in the plebiscite for the constitution, and 3) independence itself was not a certainty because the United States might still change its mind if the mandatory provisions were not complied upon (Aruego 1949:100-01). It 
was also argued by those who were against the Osias Resolution that framing a constitution also for the republic would bind the future generation of Filipino people and deprive them of the liberty and opportunity to decide their own constitution, without any mandatory provisions. There was also a group of delegates who opposed the resolution based on the argument that the PIA was clear, hence, the resolution was unnecessary. But there were also those who argued that the legal bases from the PIA which the proponents of the resolution had cited merely referred to the importance of continuity of government, that there should be a government in operation upon the U.S. withdrawal.

Yet another group of opponents provided a compelling argument and appealed to the delegates' nationalist sentiments: the PIA mandate to submit the constitution for the U.S. President approval was a reminder that Filipinos were still colonial subjects. In arguing this point, some emphasized that the convention's authority to draft a constitution derived from the PIA and this necessarily meant that there was a 'higher authority' than the authority of the Filipino people (Ibid, 665). Based on this, they argued, the convention should only draft a constitution for the commonwealth government. At the core of some of these arguments was the reservations rooted in being colonial subjects. Although reserved, theirs was a more defiant and uncompromising brand of nationalist sentiment, not wanting the constitution of the republic be subjected to any higher authority other than that of the Filipino people.

The deliberation of the Osias resolution occupied the plenary sessions of the convention for almost four weeks, from August 28 to September 21, 1934. It was becoming apparent that although non-partisanship was advocated and was an agreement between the majority (Antis) and minority (Pros) parties, the resolution had caused partisanship in the convention. In an attempt to resolve the crisis, the majority party delegates forwarded another motion to indefinitely postpone the discussion of the Osias resolution and all its amendments. Despite suspicions on the motivation of the motion by the minority delegates, minority leader Manuel Roxas finally decided to support the motion and called on everyone to end partisanship and vote on the motion based on the dictates of their conscience. The motion was approved through a majority vote, with most of those who were opposed belonging to the minority party but the crisis was resolved.

The constitution that was drafted, entitled Constitution of the Philippines, applies to both the commonwealth and republic with special provisions that would take effect upon the proclamation of Philippine independence. These provisions were specified in Article XVI of the Constitution and which were based on the PIA. These pertained to the 1) adjustment of the property rights of the United States and acknowledgement of property rights of its citizens and corporations; 2) continuity of service and serving of full terms of elected officials as if they were elected under the free and independent Philippines; 3) assumption of outstanding debts and liabilities by the Philippine government upon the withdrawal of U.S. sovereignty (the same applies for Philippine bonds issued prior to independence); 4) assumption of continuing obligations of the U.S. under the Treaty of Paris with Spain; and 5) embodiment of the aforementioned provisions (except number 2) in a treaty with the U.S. In Article XVII Section 1 of the Constitution, it was also provided that "The government established by this Constitution shall be known as the Commonwealth of the Philippines. Upon the final and complete withdrawal of the sovereignty of the United States and the proclamation of Philippine independence, the Commonwealth of the Philippines shall thenceforth be known as the Republic of the Philippines." Finally, to comply with the limitations set by the U.S. Congress and make the constitution valid for the commonwealth period, the mandatory 
provisions of the PIA governing the relationship between the U.S. and the Philippine Commonwealth were appended as an ordinance to the constitution. While the 'special provisions' correspond to the transition from a commonwealth to republic, the "Ordinance Appended to the Constitution" was provisions that solely governed the commonwealth.

The Philippine Constitution, which was ratified through a plebiscite in May 14, 1935, became the constitution for the commonwealth and for the republic, after the Philippines was granted independence by the United States on July 4, 1946. This constitution was amended once in 1940 to change the tenure of the president, allowing him re-election, and to return to a bicameral legislature. Besides these amendments, the same constitution lasted until a new constitution was promulgated under the authoritarian regime of Ferdinand Marcos in 1973. Otherwise, all the special provisions and the appended ordinance to the constitution remained part of the constitution long after independence was granted.

It was apparent in the deliberations of the Osias resolution that on the one hand, there was disagreement as to the purpose of the PIA despite its claimed 'clarity' by many of the members of the convention, and on the other, disagreement, even confusion, at least for some, of their constitution-making experience vis-à-vis the constitution-making experiences of other sovereign nations prior to the wave of decolonization. These two aspects of disagreement were rooted in the ambiguity and uniqueness of their historical and political condition. Filipinos were to be granted independence but this independence was deferred for ten years. For the meantime, they were supposed to draft a constitution that will establish and structure their government. These two dimensions of their condition were both embedded in the Philippine Independence Act, the subtitle of which stated: An Act to Provide for the Complete Independence of the Philippine Islands, to Provide for the Adoption of a Constitution and a Form of Government for the Philippine Islands, and for Other Purposes. From the title itself, with the phrase 'complete independence', it would seem that the purpose of the law with regards to the adoption of the constitution was to draft a constitution for the independent Philippines. However, this Act categorically stated in Section 1 that the constitution to be framed was for the Commonwealth government but the Act put together different aspects of the Philippine political condition and requirements with regards to the Philippines' relations with the U.S., which led to the disagreements in the convention. As the deliberations of the Osias resolution showed, many delegates interpreted the instructions of the Act differently, reading in various provisions that the U.S. Congress was instructing them to write a constitution for the republic. Not even the reminder of the intent of the law, which a couple of delegates pointed out in their speeches, changed the minds of those who argued for drafting a constitution for the republic.

The delegates' disagreements on their political status also manifested in some of their speeches on the question of sovereignty. Based on the contention of most of those who were opposed to the Osias resolution, the commonwealth government was to be under the sovereignty of the U.S. and while they were drafting the constitution, the convention's power to draft it emanated from the sovereignty of the U.S., and not from the Filipino people. In the deliberations, however, there were contentions to the opposite. One of those was Delegate Manuel Roxas', the prominent and influential leader of the minority, who argued that the constitutional convention was given the 'right' by the U.S. Congress to adopt a constitution which presupposed Filipinos' right to govern, which he equated with sovereignty. He emphasized the conception of the constitution in the 
American philosophy of constitutional law that presupposed sovereignty of the people. His explanation is worth replicating here, especially because he was one of the dominant and influential actors in the convention:

If the constitution derives its powers from the people [as Chief Justice Marshall explained in the Marbury vs. Madison case], the question may be asked: From whom we derive this power in the Constitutional Convention - from the American Congress or from the people? My reply is, from the people. The American Congress has given us the right to adopt a constitution. But the right to form a constitution presupposes the right to govern - sovereignty, as this has been defined by the ancient and modern writers. We cannot talk of a constitution in accordance with American philosophy of Constitutional Law without presupposing behind it sovereignty in the people that approve it. If, therefore, because we have the power to adopt a constitution, we must perforce admit that the people are sovereign, why does the Independence Law impose limitations on our power? The reply is evident. The American Congress, in the Independence Act, has in effect told the Filipino people: 'You have the right to govern yourselves. You can adopt and formulate a constitution for your government, but during the intermediate period and until the complete withdrawal of American sovereignty from your country, your sovereignty will be restricted by the following mandatory provisions.' These restrictions are imposed by Congress; but, Mr. President, to prove that a constitution must exclusively be the work of the people, Congress requires that the constitution must contain these mandatory provisions. That is to say, the people of the Philippine Islands by their votes must accept these mandatory provisions, otherwise the whole process provided in the Independence Law would fail and collapse (Ibid 566-67. Emphases added.).

He further added,

We come to the next question, Mr. President: If we are sovereign and draft a constitution within certain limits, to whom does the residuary of sovereignty belong? That is to say, who has the power that will bear the limitations that is imposed by Congress? Is it Congress or is it the Filipino people? In the language of American courts, who is the residuary legatee of sovereign powers, those that are not mentioned as included in the restrictions imposed by the Independence Act? My reply is, the people of the Philippine Islands. We are completely sovereign; we can adopt any constitution that we want subject the limitations imposed by Congress, but these limitations to be operative must be included by us in the constitution that we will adopt (Ibid 567, Emphases added).

Roxas was also asked to provide his definitions of sovereign powers and sovereignty. To this he replied:

Sovereignty and sovereign powers - sovereign powers are just a description of sovereignty. Sovereignty is the totality. Sovereign 
powers are exercised by the entity that has the sovereignty. And the sovereign powers may be divided, that is to say, the people, may grant certain powers or may delegate certain powers to their representative and retain the rest. Now, what happens with the law is this, Mr. Gentleman from Negros. We are given the totality of sovereignty from my viewpoint. No, there are two viewpoints here. My viewpoint is that the United States Congress, by giving us the right to draft a constitution, has given us the totality of sovereign powers or the exercise of these sovereign powers during a certain period that is limited. That is to say, you may exercise all the powers of sovereignty provided, however, that during the period of ten years, you cannot do this and you cannot do that...There is another theory as to the meaning of the sovereignty... that sovereignty cannot be transferred. The people have it as an inalienable right and sovereignty may be suspended for a while, but when the force that suspends the exercise of sovereignty is removed, sovereignty of its own force reasserts itself. Now, applying that theory to the Philippine, there is much justice in the statement. But I believe that is not the theory under which the Independence Act was passed because the American Congress in this law implies that sovereignty now resides in America. During the commonwealth, America withdraws a certain portion of that sovereignty and retains some, but at the end of the ten-year period, it finally withdraws its sovereignty (Ibid).

In his explanation, Roxas did not distinguish popular sovereignty from state sovereignty, and thus, conflated the two. His muddled notion and explanation stems from the uniqueness of the political status and the lack of models from which they could base their particular constitution-making episode. Legally speaking (if based on the Treaty of Paris 1898 and the subsequent laws passed by the U.S.), the Philippines was under the sovereignty of the United States during the period of constitution-making and even during the ten-year period of commonwealth, until the complete withdrawal of the U.S. sovereignty and despite the promise of independence. This was recognized by Delegate Kintanar when he pointed out that the mandatory provisions signified that there was a 'higher authority than the authority of the Filipino people' (PCC Vol.1 1969:665). It was clear that the Philippines, as a colony and commonwealth, did not have state sovereignty. What Roxas referred to as 'residuary sovereignty' was autonomy, which was different from sovereignty given the 'absolute' quality of sovereignty. Autonomy was not also internal sovereignty because the commonwealth government, just like the colonial administration in the Philippines prior to the constitution-making, was under the authority of the United States President and Congress. Even if the commonwealth government had a certain degree of autonomy in managing most of its domestic affairs, the U.S. President, Congress and Supreme Court could still intervene and negate their decisions or laws.

Part of the cause of the muddled notion on sovereignty which impacted on the discussion of the scope of the constitution was the democratic process which was adopted in the election of the constitutional delegates and in the ratification of the constitution through a plebiscite. Roxas and those who supported his position to draft a constitution for both the commonwealth and republic were right to argue that the delegates to the constitutional convention were representatives of the Filipino people, freely chosen by the Filipino people through democratic elections. They had reason to believe that because of this, the Filipino people were sovereign, following the American constitutional philosophy where he equates the 'power to adopt a constitution' with sovereignty of the 
people, that is, popular sovereignty, without using this particular concept. This equation of constitution-making and popular sovereignty was also because, save for the 1901 Cuban constitution-making under the auspices of the United States, there were no other models that the Philippine convention could look up to among other colonies since most of the decolonization constitution-making events took place after WWII. The other British Commonwealth governments (e.g. Canada, Australia and New Zealand) prior to this period were of settler populations whose constitutions evolved and did not go through democratically-elected constitutional conventions such as this particular Philippine constitution-making episode. What the Philippine constitutional convention saw were the models of constitution-making after a revolution, particularly that of the United States, where 'We the People' were represented in the drafting of the constitution. However, the Philippine constitution-making was not comparable to the American model they sought because there was no complete breaking of ties with the metropolitan state. The convention also did not attempt to break its ties with the U.S. by declaring themselves independent and sovereign, just as South Africa did with Britain in 1960. In other words, even if there was a degree of popular sovereignty, there was no state sovereignty.

Also, even if Filipinos were represented in the constitutional convention, their popular sovereignty was also diminished by the imposed parameters of the PIA and by the conflation of the ratification of the constitution with the vote for independence. That is, the vote for the constitution was also a vote for Philippine independence.

Other than the election of delegates, another adopted democratic procedure was the ratification of the drafted constitution by Filipinos through a plebiscite. The PIA instructed that the drafted constitution had to undergo ratification by the general electorate through a plebiscite. However, this process was problematic because it conflated two different issues in one process: ratification of the constitution and ratification of independence. The PIA stated: "If a majority of the votes cast shall be for the constitution, such a vote shall be deemed an expression of the will of the people of the Philippine Islands in favor of Philippine Independence..." (PCC Vol.VII 1969:698)

The conflation of the independence question in the plebiscite for the constitution meshed two different but almost equally important issues. As such, the provision gave no lee-way for the rejection of the drafted constitution, unless a continued colonial condition was preferred. It was not only Filipinos who found this provision, which was retained from the original bill, objectionable. Talking about the U.S. policy with regards to Philippine independence, Secretary Hurley (1933:2) in his comments on the original PIA bill pointed out "It is, to say the least, very doubtful if a just final decision could be reached by plebiscite on such an important question." This aspect of the interim constitution, however, was not so much an issue for many of the convention delegates except for those who were opposed to drafting a constitution for the republic. It was a known issue prior to the acceptance of PIA by the Philippine Legislature which neither the latter, nor the convention delegates could do anything about because it was already set by the U.S. Congress. This shows that despite the lessons learned by the U.S. in the Cuban constitution-making, the PIA was not without ambiguities. Besides the loopholes in the Act regarding the scope of the constitution to be drafted which caused so much debate, it also caused consternation and displeasure among Filipino leaders that the PIA conflated the issue of independence and the ratification of the constitution. What this shows, however, was the undeniable facticity of the Philippine colonial status.

The issue of sovereignty and how it manifested in the deliberations of the scope of the constitution shows that, ultimately, nationalist sentiments drove the delegates on 
both sides of the argument (for or against the Osias resolution) to push for their preferences. For those who supported the Osias resolution, it was an act of sovereignty, regardless of how the concept was understood. For the other side, it was a defiance of the idea of subjecting the constitution of the soon-to-be republic to the approval of colonial powers. It was also their nationalist sentiment which was called upon to end the partisanship which led to the 'indefinite postponement' of the discussion of the Osias resolution. But what was also apparent in the deliberation was that while they tried to assert their versions of nationalist sentiment, they were also very much aware of the presence of a higher authority whose approval of the constitution they had to seek. This awareness led Filipino leaders and convention leaders to seek the American officials' approval even before the convention ended. Their attitude toward the colonial power showed their pragmatic attitude towards their colonial condition. They could not be all nationalist and assertive if they want the good relations with the colonial power. This ambivalent attitude, nationalist and assertive while subservient to the colonial power, was a manifestation of the pragmatic nationalism that the constitutional convention, and the Filipino leaders, had exhibited during this constitution-making episode.

\section{CONCLUSION}

Considering the approximation of popular sovereignty through popular democratic processes and the question of state sovereignty, the Philippines, along with Cuba and Puerto Rico, did not have state sovereignty when they drafted their constitutions although they went through democratic processes. Cuba's experience in constitutionmaking of 1901 was more similar to the Philippines, and was a lesson learned for the United States, in terms of the latter's impositions on its relationship with its protectorate. Both countries drafted a constitution for their republic with the attached demands of the United States. The Filipino constitutional convention delegates could have decided to frame a constitution for the interim commonwealth period but ultimately decided against it after so much debate.

By adopting a constitution for both the republic and the commonwealth government, the framers subjected the constitution for the republic to the sovereignty of an external power and this lent doubts on the legitimacy of the constitutional process and outcome. Not only were the parameters for the constitution dictated by the U.S., but also, before the drafted Philippine Constitution underwent ratification by the Filipino people through a plebiscite, it had to be approved by the United States President to make sure that the constitution conformed to the provisions of the PIA. The democratic measures and principles, then, that could have legitimated the process and outcome were problematic. Although the constitution-making underwent democratic processes approximating popular sovereignty, there was no state sovereignty when the constitution was drafted.

The constitutional choice was, ultimately, a response to the colonial condition and an attempt to extend the space provided towards the achievement of Filipino national aspiration. It was the same aspiration for independence which made them overlook their subjection to colonial domination during this process, and instead, the fervor of finally founding a sovereign nation, though highly questionable and questioned, reigned among them. As Delegate Zavalla stated, 


\begin{abstract}
the constitution to be drafted and formulated by this body shall be submitted to the people of the Philippine Islands for ratification or rejection as provided in Section 4 of the Independence Law, the same can serve as a constitution for the Philippine Republic inasmuch as it has the stamp approval of the people. Yes, it shall have the approval of a dependent people, but not by the sovereign Filipino people. Whatever may be said in favor of the [Osias] resolution, the fact remains that the approval of the constitution to be drafted by us, by the Filipino people under American regime, is not equivalent to its ratification by a sovereign people in the exercise of their sovereign power. The people, in approving or rejecting the constitution, shall be acting as a mere mandatory of the Congress of the United States which gives us such concession subject to the limitations and conditions imposed in the Independence Law (PCC Vol.II 1969: 51)
\end{abstract}

What this constitution-making episode demonstrates was the implications of the complex historical condition for the conception and use of constitution-making by those who have undergone a transplantation of a Western political construct. If looked at the surface, the discourse adopted by Filipinos during the convention seemed similar to that of its colonizer and they patterned their decision after the American experience. Despite the difference in the historical conditions with that of their colonizer, Filipino constitution framers, to borrow Comaroff's (2003) phrase, 'transmute[d] difference into the likeness' (457). But the likeness is superficial and the fact remained that the Philippine 1935 Constitution was drafted under American sovereignty and that the same constitution had been drafted not by a free people but by colonial subjects.

\title{
REFERENCES
}

ARATO, Andrew. 2000. Civil Society, Constitution, and Legitimacy. Maryland: Rowman and Littlefield Publishers, Inc. 2009. Constitution making Under Occupation: The Politics of Imposed

Revolution in Iraq. New York: Columbia University Press.

Arato, Andrew and Jean Cohen. 2009. "Banishing the Sovereign? Internal and External Sovereignty in Arendt." Constellations 16:2: 307-330.

Arendt, H. 1965. On Revolution. New York: Viking Press.

Aruego, J. 1949. The Framing of the Philippine Constitution. Manila: University Publishing Co., Inc.

Austin, John. 1832/1995. The Province of Jurisprudence Determined. W. Rumble (ed.). Cambridge: Cambridge University Press.

Barnett, Hilaire. 2004. Constitutional and Administrative Law. Portland,Oregon: Cavendish Publishing.

Benhabib, Seyla. 2009. "Twilight of Sovereignty or the Emergence of Cosmopolitan Norms? Rethinking Citizenship in Volatile Times." Heather Gautney (ed.) Democracy, States, and the Struggle for Global Justice New York: Routledge. Pp.79-88.

Bodin, Jean. 1992. On Sovereignty. Trans. by Julian Franklin. Cambridge: Cambridge Universit Press. 
Brands, H.W. 1992. Bound to Empire: the United States and the Philippines. New York: Oxford University Press.

Comaroff, Jean and John Comaroff. 2003. "Reflections on Liberalism, Policulturalism, and ID-ology: Citizenship and Difference in South Africa." Social Identities (9:4: 445473).

Cooley, Alexander and Hendrik Spruyt. 2009. Contracting States: Sovereign Transfers in International Relations. New Jersey: Princeton University Press.

Cuaderno, M. 1937. The Framing of the Constitution of the Philippines. Manila: Philippine Education Co., Inc.

Cuba Military Governor. 1901. Report of the Military Governor of Cuba. Online at www.books.google.com. Retrieved on January 12, 2010.

Cuban Constitutional Convention. 1901. "Declaration of Relations with the United States." World Almanac and Encyclopedia. New York: New York Press Publishing Co., p.180.

Dicey, Albert Venn. 1885. Lectures Introductory to the Study of Law of the Constitution. London: Macmillan and Co.

Frank Murphy Papers. Bentley Historical Library, University of Michigan.

Friedrich, Carl. 1963. Man and His Government. New York: McGraw-Hill.

Friend, Theodore. 1965. Between Two Empires: The Ordeal of the Philippines 19291946. New Haven: Yale University Press.

Jenkins, Shirley. 1954. American Economic Policy Toward the Philippines. Stanford, CA: Stanford University Press.

Golay, Frank H. 1997. Face of Empire: United States-Philippine Relations, 1898-1946. Manila: Ateneo de Manila University Press.

Grunder, G. and Livezey, W. 1951. The United States and the Philippines. Norman: University of Oklahoma Press.

Habermas, J. 1996. Between Facts and Norms: Contributions to a Discourse Theory of Law and Democracy, trans. by William Regh. Cambridge, Mass.: MIT Press.

Hayden, Joseph Ralston. 1942. The Philippines: A Study in National Development. New York: The Macmillan Company.

Holsti, Kalevi Jaakko. 2004. Taming the Sovereigns: Institutional Change in International Politics. Cambridge: Cambridge University Press.

Hurley, Patrick. 1933. "Report to the President by the Secretary of War on H.R. 7233 Granting Philippine Independence." In Hayden Papers, Bentley Historical Library, University of Michigan.

Jackson, Robert H. 2007. Sovereignty: Evolution of an Idea. Cambridge: Polity Press.

James, Alan. 2000. "States and Sovereignty." Trevor C. Salmón and Mark F. Imber. 2000. Issues in International Relations. New York: Routledge. Pp.1-24.

Kirk, Grayson. 1936. Philippine Independence: Motives, Problems, and Prospects. New York: Farrar and Rhinehart, Inc.

Kis, Janos. 2003. Constitutional Democracy. New York: Central University Press.

Leibowitz, Arnold. 1989. Defining Status: A Comprehensive Analysis of United States Territorial Relations. Norwell, MA: Academic Publishers.

Malanczuk, Peter and Michael Barton and Akehurst. 1997. Modern Introduction to International Law. New York: Routledge.

McWhinney, Edward. 1981. Constitution-making: Principles, Process, Practice. Toronto: University of Toronto Press. 
Nohlen, Dieter, Florian Grotz, and Christof Hartmann. 2001. Elections in Asia and the Pacific: A Data Handbook. Oxford: Oxford University Press.

Pérez, Louis. 1986. Cuba Under the Platt Amendment, 1902-1934. Pittsburgh: University of Pittsburg Press.

1988. Cuba: Between Reform and Revolution. Oxford: Oxford University Press.

Philippine Constitutional Convention. (1969). Proceedings of the Constitutional Convention: As Faithfully Reproduced from the Records kept by Dr. Jose P. Laurel Volume I-VII (PCC). Manila: Lyceum Press.

Philpott, Daniel. 1997. "Ideas and the Evolution of Sovereignty." Sohail H. Hashmi (ed.). State Sovereignty: Change and persistence in International Relations. University Park, PA: Pennsylvania State University Press. Pp.15-49.

Pomeroy, William. 1992. The Philippines: Colonialism, Collaboration, and Resistance. New York: International Publishers Co., Inc.

Robbers. Gerhard (Ed.). 2007. Encyclopedia of World Constitutions. New York, NY: Facts on File, Inc.

Russell, Peter H. 2004. Constitutional Odyssey: Can Canadians Become a Sovereign People? Toronto: University of Toronto Press Inc.

Sieyes, E.J. 1964. What is the Third Estate? Trans.by M. Blondel. New York: Frederick A. Praeger, Publisher, 1964.

Recebido em: 30 de abril de 2016.

Aprovado em: 15 de maio de 2016. 